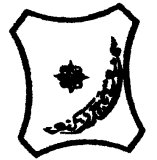

Bayero Journal of Pure and Applied Sciences, 5(1): 66 - 71

Received: April 2011

Accepted: April 2012

ISSN $2006-6996$

\title{
REACTIONS OF IMPROVED COWPEA GENOTYPES TO SOME MAJOR DISEASES IN A SORGHUM-BASED CROPPING SYSTEM IN THE SUDAN SAVANNA OF NIGERIA
}

\author{
*Mohammed, I. B. ${ }^{1}$, Wudil, B. S. ${ }^{2}$ and Garko, M. B. A. ${ }^{1}$ \\ ${ }^{1}$ Department of Agronomy, Bayero University, Kano, Nigeria. \\ ${ }^{2}$ Department of Crop Protection, Bayero University, Kano, Nigeria. \\ *Correspondence author: ibabamohd@yahoo.co.uk
}

\begin{abstract}
The study was carried out to investigate the susceptibilities of some improved cowpea genotypes to infection and damage due to bacterial blight, smut and cowpea aphid-borne mosaic virus CABMV in a sorghum-based cropping system during 1999 and 2000 at Minjibir, Kano, Nigeria. Treatments consisted of six (6) genotypes made up of one (1) local Danila and five (5) improved (IT90K-277-2, IT95K-1090-3, IT95K-222-14, IT96D-666 and IT96D-759) and in a four (4) row arrangements (1S:1C, 2S:2C, 1S:2C, and 2S:4C, reflecting millet to cowpea rows). These were laid out in a split plot design with three replications. There was a significant effect $(P \leq 0.05)$ of cowpea genotype on bacterial blight. In both seasons IT96D-666 recorded the highest for bacterial blight and smut damage. In 1999, Danila along with improved genotypes recorded lower ratings for blight, while in 2000 only Danila and IT95K-277-2 recorded the highest protection against bacterial blight. For smut with the exception of IT96D-666, the other (Danila, IT95K-277-2, IT95K-1091-3, IT95K-22214 and IT96D-759) recorded statistically comparable lower damage ratings. In both seasons IT95K-277-2 recorded the least incidence and severity of leaf virus. Although the other genotypes had virtually similar and higher ratings in both or one of the two seasons, Danila and IT95K-1091-3 recorded consistently higher values. In the two seasons Danila produced significantly higher Total Dry Matter (TDM) and the other semi-determinate genotypes had comparable values. In both seasons IT95K-222-14 consistently out-yielded the other genotypes but it had statistically similar grain yield with IT95K-277-2 in 2000. Row arrangement had a significant effect on bacterial blight in 1999, whereas planting cowpea at 1S:1C recorded the least infection while the highest rating was obtained at 25:4C row arrangement. Incidence and severity of leaf virus were not affected by row arrangement. In both seasons TDM and grain yields were significantly higher at 2S:4C while the least values were recorded at 1S:1C row arrangement was superior to the row arrangement. The genotype and row arrangement interaction indicated that planting of IT95K-222-14 at 25:4C row arrangement produced the highest grain yield.
\end{abstract}

Keywords: Cowpea genotypes, Bacterial Blight, Smut Disease, Cowpea Aphid-Borne Mosaic Virus (CABMV), Intercropping and Sudan savanna

\section{INTRODUCTION}

Cowpea (Vigna unguiculata L. Walp) is a major source of protein and of considerable importance for human nutrition in tropical regions of Africa (Gowda et al., 2000). In West Africa, cowpea is second in importance after groundnut, with Nigeria accounting for over $70 \%$ of the total world production (Singh et al., 2002). Cowpea constitutes the cheapest source of dietary protein for low income sector of the population (Rachie, 1985). It is estimated that cowpea supplies $40 \%$ of the daily protein requirements to most people in Nigeria (Maluba et al., 1997). It was further observed that of all the leguminous crops, cowpea appears to be one of the most important in sustainable soil fertility management (IITA, 1990), as it can fix up to $88 \mathrm{~kg} \mathrm{Nha}^{-1}$ (Fatokun et al., 2002).

Cowpea yields, especially among the subsistence farmers, are generally low due to several factors, but diseases such as leaf virus, bacterial blight and smut remain major constraints to sustained high cowpea grain yields (Soyinka et al., 1997). Bacterial blight induced by Xanthomonas axono-podis $p v$ vignicola has been reported to have wide spread in areas where cowpea is grown (Ajeigbe et al., 2008). Yield loses of up to $87 \%$ due to leaf viruses have reported in Nigeria (Soyinka et al., 1997) of which cowpea aphid-borne mosaic virus (CABMV) disease has been the major agent in northern Nigeria (Raheja and Leleji, 1974). Cowpea leaf smut (Entyloma vignae) is a serious disease of cowpea in Nigeria, and symptoms are very prominent on the leaves (Anon., 2009). The pathogen forms dark ashy-grey to sootyblack lesions while young lesions have yellow halos. It is best controlled by use of disease-free or resistant varieties and rouging of infected plant (Adejumo et al., 2001; Anon., 2009). Under the traditional systems in the Sudan savanna of Nigeria farmers inter-crop cereals with local cowpea cultivars which produce poor grain yields. Currently, the International Institute of Tropical Agriculture (IITA) has developed improved genotypes that have moderate to high resistance/tolerance to major cowpea diseases. These genotypes needed to be evaluated for their reactions to major disease pathogens and response to intercropping systems. 
Therefore, this study was aimed at examining the reactions of some cowpea genotypes to bacterial blight, leaf virus and smut as affected by cowpea variety and row arrangement in the Sudan savanna region of Nigeria.

\section{MATERIALS AND METHODS}

Field trials were conducted at the IITA Research Farm, Minjibir, Kano (lat. $12^{0} 08^{\prime} \mathrm{N}$ long. $8^{0} 32^{\prime} \mathrm{E}, 500 \mathrm{~m}$ above sea level) in the 1999 and 2000 cropping seasons. The soil of the experimental site was sandy loam. Treatments consisted of a combination of six (6) cowpea genotypes made up of one (1) local Danila and five (5) improved (IT90K-277-2, IT95K-1090-3, IT95KD-222-14, IT96D-666 and IT96D-759) and four (4) row arrangements $(1 \mathrm{~S}: 1 \mathrm{C}, 2 \mathrm{~S}: 2 \mathrm{C}, 1 \mathrm{~S}: 2 \mathrm{C}$, and $2 \mathrm{~S}: 4 \mathrm{C}$, reflecting millet to cowpea rows). The treatments were laid out in a split plot design with row arrangement and cowpea genotype as main and subtreatments respectively. The gross plots varied from 14 ridges $75 \mathrm{~cm}$ apart by $6 \mathrm{~m}$ long to 6 ridges by long and the net plot from 6 ridges $4 \mathrm{~m}$ long to 2 ridges $4 \mathrm{~m}$ long, depending on the row arrangement. The plots received a basal application of $30 \mathrm{~kg} \mathrm{~N}, 30 \mathrm{~kg} \mathrm{P}_{2} \mathrm{O}_{5}$ and $30 \mathrm{~kg} \mathrm{k}_{2} \mathrm{O} / \mathrm{ha}$ in form of Urea, Single Superphosphate and Muriate of potash respectively before planting. Sorghum was top-dressed with $30 \mathrm{~kg}$ $\mathrm{N} /$ ha at 5 weeks after planting. The seeds (cowpea and millet) dressed with Farnasan D, were sown at 20 $\mathrm{cm}$ on $75 \mathrm{~cm}$ between ridges for cowpea and $30 \mathrm{~cm}$ on $75 \mathrm{~cm}$ ridges for sorghum. Sorghum was sown two weeks after cowpea in 1999, but in 2000 the crops were planted simultaneously. The variation was determined by the onset and the establishment of the rains. The crops were sown as per the row arrangement, weeds were controlled using double spray of Delfos at the rate of 1 litre/ha at 40 days after sowing (DAS) i.e at flowering stage and 55 DAS (podding stage).

At maturity data were recorded for bacterial blight, smut and for incidence and severity of virus, and for total dry matter and grain yield. Bacterial blight damage on cowpea was rated using 1-9 visual rating scale as described by Jackai and Singh (1988): $1=$ no symptoms; 2 = pinhead lesions on lower leaf surfaces; 3 $=$ pinhead lesions coalescing slight leaf blight; $5=\tan$ to orange coloured lesions with yellow halo, typically on leaf margins; $7=$ spreading lesions on 25 to 50 per cent of leaf area; $9=$ extensive leaf necrosis confined to lower stem. Screening for leaf virus and smut were based on $0-5$ scale: $0=$ no plants showing symptoms (immune); $1=1-5$ per cent of plants showing symptoms (resistant); $2=5-15$ per cent of plants showing symptoms (moderately resistant); $3=15-25$ per cent of plants showing symptoms (moderately susceptible); $4=25-50$ per cent of plants showing symptoms (susceptible); $5=>50$ per cent of plants showing symptoms (highly susceptible). The data were analyzed statistically as described by Snedecor and Cochran (1967). Multiple comparisons of the means were done using Duncan's Multiple Range Test (Duncan, 1955).

\section{RESULTS}

Bacterial blight and smut diseases were significantly affected by cowpea genotypes in both seasons, although in 1999 only cowpea genotype IT96D-666 recorded the highest damage by bacterial blight where all the other genotypes were comparable (Table 1 ). However in 2000, Danila and IT90K-277-2 were found to have the least damage by bacterial blight and these were followed by all other three cultivars, while IT96D-666 appeared the worst affected by bacterial blight. Similarly, smut disease was significantly affected by cowpea genotypes in both seasons. In 1999, cowpea variety, IT95-1091-3 recorded the least damage by smut disease and this was followed by Danila and all other three cowpea cultivars which were found to be comparable, while IT96D-666 offered the highest damage when compared to all other cultivars. In 2000 however, all the cowpea varieties were comparable, except IT96D-666 which was statistically different and recorded the highest cowpea damage when compared to other genotypes.

Blight disease was significantly affected ( $P \leq$ 0.05 ) by row arrangement only in 1999 , while there was no statistical difference among the treatments in 2000. Sowing cowpea at $1 \mathrm{~S}: 1 \mathrm{C}$ row arrangement offered the best protection against the cowpea blight disease followed by $2 \mathrm{~S}: 2 \mathrm{C}$ and $1 \mathrm{~S}: 2 \mathrm{C}$ row arrangements which were comparable. Cowpea sown at $2 \mathrm{~S}: 2 \mathrm{C}$ row arrangement recorded the highest damage by cowpea blight disease in 1999. The interaction effect of cowpea genotypes and row arrangement was not significant throughout the season.

The incidence and severity of leaf virus was significantly affected by cowpea genotype (Table 2). In 1999, all the cowpea genotypes recorded comparable results and were significant different to IT90K-277-2 which offered the least damage. Cowpea genotype IT90K-277-2 recorded the best protection against cowpea leaf virus which was followed by IT95K-222-14, IT96D-666 and IT96-759 which were comparable and better than the IT95k-1091-3. The cowpea cultivar Danila local was found to have recorded the highest incidence of the leaf virus disease on cowpea in 2000. In 1999, significant effects were recorded on the severity of leaf virus on different cowpea cultivars. Both Danila local and IT95K-1091-3 were comparable and recorded the highest leaf virus severity in both seasons. All the other cowpea genotypes were comparable except IT90K-277-2 which offered to be superior in checking leaf virus disease severity in 2000. However, there were no significant effects among all the row arrangements and the interactions between cowpea genotypes and row arrangement were insignificant.

Cowpea dry matter was significantly affected by genotypes in both seasons (Table 3 ). Danila local recorded the highest dry matter compared to other cowpea genotypes this was followed by IT90K-277-2 and IT95K-222-14 which are found to be similar. Cowpea varieties, IT95k-1091-3, IT96D-666 and IT96D-759 were similar and inferior to the former genotypes in 1999. 
However in 2000, Danila local produced the highest dry matter compared to all other genotypes which were comparable. Cowpea grain yield was significantly affected by genotypes in both seasons (Table 3). In 1999, the improved cowpea cultivar IT95K-222-14 produced significantly higher grain yield than all other cowpea genotypes. The cowpea cultivar IT90k-277-2 ranked second followed by IT96D-759, IT95K-1091-3, Danila local and IT96D-666 respectively. Cowpea cultivar IT95K-1091-3 produced the second highest cowpea grain yield. Danila local and an improved IT96D-666 were similar and superior to IT96D-759 which recorded the least cowpea grain yield.

The row arrangement of had significantly affected cowpea dry matter and grain yield in both seasons. Cowpea sown at 2S:4C row arrangement recorded the highest cowpea dry matter followed by $2 \mathrm{~S}: 2 \mathrm{C}$ and $1 \mathrm{~S}: 2 \mathrm{C}$ which were comparable, while $1 \mathrm{~S}: 1 \mathrm{C}$ row arrangement produced the least cowpea dry matter weight in both seasons. However, cowpea grain yield was significantly affected by row arrangement with $2 \mathrm{~S}: 4 \mathrm{C}$ producing superior to the other row arrangements which were all comparable in both seasons. The interaction of cowpea genotypes and row arrangement was significant only on cowpea grain yield in 1999 (Table 4). Except for IT96D-759 all the genotypes recorded similar grain yields at $1 \mathrm{~S}: 1 \mathrm{C}$, $2 \mathrm{~S}: 2 \mathrm{C}$ and $1 \mathrm{~S}: 2 \mathrm{C}$ row arrangements. However, for IT96D-759, sowing at 2S:2C row arrangement produced significantly higher grain yield compared with 1S:1C followed by $1 \mathrm{~S}: 2 \mathrm{C}$ and $2 \mathrm{~S}: 4 \mathrm{C}$ row arrangements, which had comparable values.

Table 1. Effect of cowpea genotype and row arrangement on bacterial blight and smut on cowpea in mixture with sorghum at Minjibir, Kano State

\begin{tabular}{|c|c|c|c|c|}
\hline \multirow{2}{*}{$\begin{array}{l}\text { Treatments } \\
\text { Cowpea genotype }\end{array}$} & \multicolumn{2}{|c|}{ Bacterial blight } & \multicolumn{2}{|c|}{ Smut } \\
\hline & 1999 & 2000 & 1999 & 2000 \\
\hline Danila & $1.13 b$ & $1.71 b c$ & $1.67 a b$ & $1.5 b$ \\
\hline IT90K-277-2 & $1.08 b$ & $1.38 \mathrm{c}$ & 1.79ab & $1.63 b$ \\
\hline IT95K-1091-3 & $1.04 \mathrm{~b}$ & $2.13 a b$ & $1.5 \mathrm{~b}$ & $1.08 \mathrm{~b}$ \\
\hline IT95K-222-14 & $1.17 \mathrm{~b}$ & $2.08 \mathrm{ab}$ & $1.87 a b$ & $1.67 \mathrm{~b}$ \\
\hline IT96D-666 & $1.42 \mathrm{a}$ & $2.5 a$ & $2.42 \mathrm{a}$ & $2.54 a$ \\
\hline IT96D-759 & $1.13 b$ & $2.13 a b$ & $1.75 a b$ & $1.57 \mathrm{~b}$ \\
\hline $\mathrm{SE} \pm$ & 0.06 & 0.15 & 0.25 & 0.23 \\
\hline Row arrangement & & & & \\
\hline $1 S: 1 C$ & $1.00 \mathrm{c}$ & 1.75 & 1.75 & 1.58 \\
\hline $2 S: 2 C$ & $1.14 b$ & 2.00 & 1.72 & 1.44 \\
\hline $1 \mathrm{~S}: 2 \mathrm{C}$ & $1.11 b$ & 2.14 & 1.92 & 1.74 \\
\hline $2 S: 4 C$ & $1.39 a$ & 2.06 & 1.94 & 1.89 \\
\hline $\mathrm{SE} \pm$ & 0.02 & 0.15 & 0.19 & 0.27 \\
\hline $\mathrm{CG} \overline{\mathrm{x}} \mathrm{RA}$ interaction & ns & ns & Ns & ns \\
\hline
\end{tabular}

Means followed by the same letter (s) within treatment are not significantly different at 5\% using DMRT. NS $=$ Not Significant

Table 2. Effect of cowpea genotype and row arrangement on incidence and severity of leaf Mosaic virus on cowpea in mixture with sorghum at Minjibir, Kano State

\begin{tabular}{|c|c|c|c|c|}
\hline \multirow[t]{2}{*}{ Treatments } & \multicolumn{2}{|c|}{ Incidence of leaf virus } & \multicolumn{2}{|c|}{ Severity of leaf virus } \\
\hline & 1999 & 2000 & 1999 & 2000 \\
\hline \multicolumn{5}{|l|}{ Cowpea genotype } \\
\hline Danila & $2.58 \mathrm{a}$ & $2.75 a$ & $2.63 a$ & $2.75 a$ \\
\hline IT90K-277-2 & $1.46 b$ & $1.00 \mathrm{~d}$ & $1.79 b$ & $1.00 \mathrm{~d}$ \\
\hline IT95K-1091-3 & $2.63 a$ & $2.00 \mathrm{~b}$ & $2.83 a$ & $3.00 a$ \\
\hline IT95K-222-14 & $2.13 a$ & $1.42 \mathrm{c}$ & $1.96 \mathrm{~b}$ & $1.42 \mathrm{~b}$ \\
\hline IT96D-666 & $2.08 a$ & $1.42 \mathrm{C}$ & $1.88 \mathrm{~b}$ & $1.42 b$ \\
\hline IT96D-759 & $2.17 a$ & $1.42 \mathrm{c}$ & $2.13 b$ & $1.42 b$ \\
\hline $\mathrm{SE} \pm$ & 0.19 & 0.12 & 0.16 & 0.11 \\
\hline \multicolumn{5}{|l|}{ Row arrangement } \\
\hline $1 \mathrm{~S}: 1 \mathrm{C}$ & 2.19 & 1.72 & 2.08 & 1.83 \\
\hline $2 S: 2 C$ & 2.22 & 1.61 & 2.17 & 1.72 \\
\hline $1 \mathrm{~S}: 2 \mathrm{C}$ & 2.08 & 1.78 & 2.36 & 2.00 \\
\hline $2 S: 4 C$ & 2.19 & 1.56 & 2.19 & 1.78 \\
\hline $\mathrm{SE} \pm$ & 0.21 & 0.07 & 0.11 & 0.08 \\
\hline $\mathrm{CG} \overline{\mathrm{x}} \mathrm{RA}$ interaction & ns & ns & ns & ns \\
\hline
\end{tabular}

Means followed by the same letter (s) within treatment are not significantly different at 5\% using DMRT. NS = Not Significant 
Table 3. Effect of cowpea genotype and row arrangement on total dry matter and grain yield of cowpea in mixture with sorghum at Minjibir, Kano State.

\begin{tabular}{|c|c|c|c|c|}
\hline \multirow[t]{2}{*}{ Treatments } & \multicolumn{2}{|c|}{ Total dry matter at 12 WAS (g) } & \multicolumn{2}{|c|}{ Grain yield (kg/ha) } \\
\hline & 1999 & 2000 & 1999 & 2000 \\
\hline \multicolumn{5}{|l|}{ Cowpea genotype } \\
\hline Danila & $62.86 a$ & $41.88 \mathrm{a}$ & $424 d$ & $660 b c$ \\
\hline IT90K-277-2 & $43.85 b$ & $36.56 b$ & $682 b$ & $999 a$ \\
\hline IT95K-1091-3 & $39.32 b c$ & $35.46 b$ & $554 \mathrm{c}$ & $772 b$ \\
\hline IT95K-222-14 & $42.83 b$ & $35.82 b$ & $835 a$ & $938 a$ \\
\hline IT96D-666 & $36.43 c$ & $34.07 b$ & $340 d$ & $632 b c$ \\
\hline IT96D-759 & $33.84 c$ & $32.69 b$ & $607 b c$ & $558 \mathrm{c}$ \\
\hline $\mathrm{SE} \pm$ & 2.12 & 1.24 & 34.22 & 53.81 \\
\hline \multicolumn{5}{|l|}{ Row arrangement } \\
\hline $1 \mathrm{~S}: 1 \mathrm{C}$ & $33.24 c$ & $25.66 c$ & $410 b$ & $604 b$ \\
\hline $2 \mathrm{~S}: 2 \mathrm{C}$ & $42.72 b$ & $36.15 b$ & $462 b$ & $675 b$ \\
\hline $1 \mathrm{~S}: 2 \mathrm{C}$ & $44.40 \mathrm{~b}$ & $37.46 \mathrm{~b}$ & $497 b$ & $737 b$ \\
\hline $2 S: 4 C$ & $52.38 \mathrm{a}$ & $45.05 a$ & $926 a$ & $1023 a$ \\
\hline $\mathrm{SE} \pm$ & 1.21 & 0.79 & 75.66 & 64.35 \\
\hline $\mathrm{CG} \overline{\mathrm{x}} \mathrm{RA}$ interaction & ns & ns & $*$ & ns \\
\hline
\end{tabular}

Means followed by the same letter (s) within treatment are not significantly different at 5\% using DMRT.

NS = Not Significant

$*$ = Significant Interaction

Table 4: Interactive effect of cowpea genotype and row arrangement on grain yield ( $\mathrm{kg} / \mathrm{ha})$ of cowpea intercropped with sorghum at Minjibir, in 1999.

\begin{tabular}{lcccccc} 
Treatment & & \multicolumn{2}{c}{ Cowpea Genotype } \\
Row & Danila & IT90K-277- & IT95K-1091- & IT95K-222- & IT96D- & IT96D- \\
Arrangement & & $\mathbf{2}$ & $\mathbf{3}$ & $\mathbf{1 4}$ & $\mathbf{6 6 6}$ & 759 \\
\hline $1 S: 1 C$ & $317 \mathrm{efg}$ & $484 \mathrm{c}-\mathrm{f}$ & $354 \mathrm{efg}$ & $670 \mathrm{c}$ & $269 \mathrm{fg}$ & $619 \mathrm{~cd}$ \\
$2 \mathrm{~S}: 2 \mathrm{C}$ & $404 \mathrm{~d}-\mathrm{g}$ & $655 \mathrm{c}$ & $446 \mathrm{c}-\mathrm{g}$ & $617 \mathrm{~cd}$ & $235 \mathrm{~g}$ & $1069 \mathrm{~b}$ \\
$1 \mathrm{~S}: 2 \mathrm{C}$ & $374 \mathrm{efg}$ & $622 \mathrm{~cd}$ & $424 \mathrm{~d}-\mathrm{g}$ & $675 \mathrm{c}$ & $369 \mathrm{efg}$ & $415 \mathrm{~d}-\mathrm{g}$ \\
$2 \mathrm{~S}: 4 \mathrm{C}$ & $601 \mathrm{~cd}$ & $969 \mathrm{~b}$ & $994 \mathrm{~b}$ & $1377 \mathrm{a}$ & $546 \mathrm{cde}$ & $312 \mathrm{fg}$ \\
SE \pm & & & 98.08 & & & \\
\hline
\end{tabular}

Means followed by the same letter (s) within treatment are not significantly different at 5\% using DMRT.

\section{DISCUSSION}

The present study revealed that both bacterial blight and smut diseases were significantly affected by cowpea genotypes in both seasons although the reactions of genotypes to the pathogens differed across the seasons. The cowpea genotypes differ in many respects; growth habits, maturity periods, as well as in their inherent resistance/ tolerance or susceptibility to attack by diseases. Thus, it is not unexpected that they reacted differently to the disease pathogens. Variety IT96D-666 recorded the highest attack by both bacterial blight and smut probably because of its high susceptibility to the disease pathogens. However, few of the improved genotypes exhibited comparable disease incidence because their genetic compositions are alike. For both pathogens, the effects were highly variable across the two seasons. According to (Mohammed and Miko, 2007) variability of environmental factors such as rainfall, temperature and humidity, has great influence on incidence and severity of crop diseases. This postulation appeared to hold true in the present study as in the 1999 season was wetter $(718.7 \mathrm{~mm})$ than $2000(486.6 \mathrm{~mm})$. Thus, the varied effects in the two seasons suggested that differences in weather conditions in the two seasons might have had significant influence on the pathogens. In the wetter
1999 cropping season, the cool and humid conditions characteristic of high rainfall areas could have predisposed susceptible genotypes to smut attack.

Cowpea genotype IT90K-277-2 recorded the least damage by leaf virus disease in the two seasons which could be associated with its superior inherent resistance to the disease attack over the other genotypes. Similar findings were also reported by Singh (1999) who reported similar superiority of IT90K-277-2 over the other improved varieties. Sharma and Franzmann (2000) also observed that variations in the susceptibilities and resistance among genotypes could be due to differences in their genetic make up. In 2000, cowpea cultivar Danila recorded the highest leaf virus damage, suggesting that plant type had greatly affected the incidence of the leaf virus disease, since large succulent canopies (large leaf areas) typical of local cultivars are likely to be predisposed to viral attack as leaves are the major sites of infection (Jackai and Singh, 1988). The severity of leaf virus disease was significantly high on Danila and IT95K-1091-3 in both seasons probably because similar trend was observed for incidence. For Danila, its susceptibility might be due to its spreading and late maturing nature which probably predisposes the crop to the disease pathogens over a period of time. 
The results showed that both disease incidence and severity were low in the wetter cropping season (1999) than in 2000 season and this could be related to the favorable climatic conditions of the latter season which supported spread and survival of diseases (Mohammed and Miko, 2007).

Cowpea dry matter was significantly affected by genotypes in both seasons with Danila cultivar recording the highest dry matter compared to other improved cultivars, suggesting that it had a long maturity period which is one of the common features of the local cowpea genotypes (Terao, et al., 1997). While the dry matter recorded by some cowpea genotypes especially IT95K-277-2 and IT95K-222 -14 was probably because some of them are dual purpose (Singh, 1999). The superior dry matter of Danila in spite of its being heavily attacked the particularly leaf virus could be due to its low harvest index (Terao, et al., 1997) and moderate tolerance to major diseases (Singh, 2002). The significantly high grain yield of IT95K-222-14 could be associated with its high yield potential combined with superior resistance or tolerance to the three disease pathogens, and to major insect pests (Singh, 1999). Genotypes Danila and IT96D-759 recorded low grain yield most probably because of high or severe blight, smut and leaf virus damage as well as their poor inherent ability to produce high grain yield.

Cowpea sown in $1 \mathrm{~S}: 1 \mathrm{C}$ row arrangement was better protected against the cowpea blight disease because at narrower spacing the sorghum had offered sufficient barrier for pathogen transfer to the adjacent cowpea plants than at $2 \mathrm{~S}: 4 \mathrm{C}$ row arrangement where transmission can easily be achieved by rain splash and flowing water. Row arrangement did not affect disease incidence and severity of leaf virus. A similar result on no effect of cropping system on cowpea

\section{REFERENCES}

Adejumo, T. O., D. A. Florni and T. Ikotun (2001). Screening of cowpea cultivars for leaf smut. http://www.sciencedirect.com/science? $\mathrm{Ob}=$ articleURL down loaded (2011).

Ajeigbe, H. A., Singh, B. B. and Amechebe, A. M. (2008). Field evaluation of improved cowpea lines for resistance to bacterial blight, virus and Striga under natural infestation in the West African savannas

Anonymous (2009). Leaf smut, Cowpea Apid-borne Mosaic Virus and Bacterial Blight. http://cropgenebank.sgrp.cgiar.org/index.ph p?option $=$ com

Boudreau, M. A. (1993). Effect of intercropping with maize on severity of angular bean spot of bean in Kenya. Plant Pathology, 42, 16-25.

Duncan, D.B. (1955). Multiple range and Multiple F. test. Biometrics 11. 1-42.

Fatokun, C. A., Tarawali, S.S., Singh, B. B. Korimawa, P. M. and Toma, M. (2002). Challenges and opportunities for enhancing sustainable cowpea production. Proc. of the world virus was reported by Boudreau (1993). However, it is probable that differences in maturity period between cowpea (75 to 87 days) and the local sorghum (125 days) could account for the no effect; by the time cowpea matured the sorghum plants were still small and had not form sufficient physical barrier within the plots to influence disease spread and damage across the different row arrangements.

Cowpea dry matter and grain yield were significantly affected by the row arrangement in both seasons. Sowing cowpea at $2 \mathrm{~S}: 4 \mathrm{C}$ row arrangement out-yielded the other arrangements with the 1S:1C recording the least values. This could be attributed to the fact that the 4 rows of cowpea were so wide and had enjoyed minimum competition for environmental resources particularly light which is the most limiting factor for crops in mixtures (Terao, et al., 1997). The interaction of the cowpea genotypes and row arrangement in 1999 indicated that planting of IT95K222-14 at 2S:4C row arrangement gave the highest grain yield. This showed that higher yielding genotypes needs to be planted at wider row strips to optimize resource utilization and minimize competition especially for light.

\section{CONLUSION}

The present study suggests that sorghum-cowpea intercrop and the use of improved varieties may reduce the effect of blight and leaf virus damage, incidence and severity thereby improving the cowpea dry matter and grain yield. Also, it was found that IT90K-277-2 and IT95K-222-14 had moderate to high tolerance to bacterial blight, leaf virus and smut produced higher grain yield while sowing of cowpea at $2 \mathrm{~S}: 4 \mathrm{C}$ row arrangements gave higher dry matter and grain yields of cowpea than the other treatments.

cowpea conference III held at the International Institute of Tropical Agriculture (IITA), Ibadan, Nigeria. 4-8 September, 200 IITA, Ibadan, Nigeria. pp. 214-220.

Gowda, B. S., Miller, JL., Rubin S. S., Sham D. L. and Timko, M. P. (2000). Isolation, sequencing and mapping of resistnace gene analogs from cowpea (Vigna unguicualta L. Walp). In: C.A Fatokun, S.A. Tarawali, B. B. Singh, P. M. Kormowa and M. Tawo (Eds). Challenges and opportunities for enhancing sustainable cowpea production. Proc. of the world cowpea conference III held at the International Institute of Tropical Agriculture (IITA), Ibadan, Nigeria. 4-8 September, 200 IITA, Ibadan, Nigeria. pp. 167-184.

International Institute of Tropical Agriculture (IITA). (1990). Cassava in Tropical Africa. A reference manual, $176 \mathrm{pp}$.

Jackai, L.E.N. and S.R. Singh (1988). Screening Techniques for host plant resistance to insect pests of cowpea. Tropical Grain Legume Bulletin 35: 2-18 IITA Reprint Series. 
Maluba, N. E., Dabire, C. Sub, J.B. and Drabo, I. (1997). Technologies from cowpea production based on genetic and environmental manipulations in the semi-arid tropics. A Publication of the Semi-Arid Food Grain Research and Development (SAFGRAD) Agency of the Scientific Technical and Research Commission of OUA, Burkino Faso, 56 pages.

Mohammed, I. B. and Miko, S. (2007). Climatic variables under rain-fed and irrigated crop production: A Basis for yield variation. Journal of Science, Management and Technology Vol. 1 No. 3. pp 26-31.

Raheja, A. K. Leleji, O. I. (1974). An Aphid-borne virus disease of irrigated cowpea in Northern Nigeria. Plant disease Reporter: 58:102801084.

Rachie, K. O. (1985). Introduction of cowpea research, production and utilization, edited by Singh, S. R. Rachie, John Wiley and Sons, Chichester, U. K.

Soyinka, S. A., Thottappilly, G. and Anno-Nyako, F. O. (1997). Survey of virus incidence and distribution in Nigeria. International Journal of Pest Management. $\quad$ 43(2): 127-132.

Snedecor, G.W. and Cochran, W.G. (1967). Statistical methods. The Iowa State University Press, Ames, Iowa. U.S.A. 507pp.

Singh, B. B., Ehlers, J.D., Sharma, B. and Frreire Filho, F. R. (2002). Recent progress in cowpea breeding. In: C.A Fatokun, S.A. Tarawali, B. B. Singh, P. M. Kormowa and M. Tawo
(Eds). Challenges and opportunities for enhancing sustainable cowpea production. Proc. of the world cowpea conference III held at the International Institute of Tropical Agriculture (IITA), Ibadan, Nigeria. 4-8 September, 200 IITA, Ibadan, Nigeria. pp. 22-40.

Thottappilly, G., Rossel, R. W. (1985). World-wide occurrence and distribution of virus disease. In: Cowpea research, production and utilization. Edited by S. R. Singh and K.O. Rachie. John Wiley and Sons, Chichester, U. K. pages 155-171.

Terao, T., I. Watanabe, R. Matsunaga, S. Hakoyama, and B.B. Singh (1997). Agro-physiological constraints in intercropped cowpea: an analysis. Pages 129 - 140 In Advances in cowpea research edited by B.B. Singh, D.R. Mohan Raj, K.E. Dashiell, and L.E.N. Jackai co-publication of International Institute of Tropical Agriculture (IITA) and Japan International Research Canter for Agricultural Sciences (JIRCAS), IITA Ibadan, Nigeria.

Sharma, H. C. and Franzanmann, B. A. (2000). Biology of the legume pod borer, Maruca vitrata (Fabricius) and its damage to pigeon pea and Adzuki bean. Insect Science and its Application. 20(2): 99-108.

Singh, B.B. (1999). Evaluation of improved breading lines under 1 cereal: 1 cowpea row intercropping. pp. 34-35. IITA Annual Report (1999). Project 11 - Cowpea - Cereals Systems Improvement in the Savanna. 